\title{
Rypsin itämisen ja kasvuun lähdön edistäminen
}

\author{
Katri Pahkala, Hannu Känkänen, Pirjo Peltonen-Sainio, Erja Huusela-Veistola \\ MTT Kasvintuotannon tutkimus, 31600 Jokioinen, sähköposti: etunimi.sukunimi@mtt.fi
}

\section{Tiivistelmä}

Kasvukauden lyhyys on määrävä tekijä rypsin viljelyssä ja jalostuksessa. Rypsi kylvetään pääviljelyalueella yleensä toukokuun kahden ensimmäisen viikon aikana. Tärkeimpiä tekijöitä rypsin viljelyn onnistumisessa on tasainen ja nopea taimettuminen, jolloin myös edellytykset kasvuston hyvälle jatkokehitykselle ovat olemassa. Riittävän nopea taimettuminen heikentää rikkakasvien kilpailua ravinteista ja lyhentää tuholaisille altista taimivaihetta.

Rypsin siemenen koko on vain kymmenesosa viljan jyvästä. Ristikukkaisilla kasveilla itämiseen tarvittava vararavinto (öljy, hiilihydraatit, valkuaisaineet) on sirkkalehdissä, joita ympäröi siemenkuori. Itämisen alkaessa vesi imeytyy siemeneen nopeasti. Vedenoton hidastuessa entsyymitoiminnat vilkastuvat ja meristeemiset muutokset alkavat. Kun vedenotto nopeutuu uudelleen, siemenkuori rikkoutuu ja sirkkajuuri työntyy esiin. Sirkkalehdet nousevat sirkkavarren kannattamina maanpinnalle nostaen siemenkuoren jäännökset mukanaan.

Siemenen itämisen edellytyksenä on riittävä kosteus, sopiva lämpötila, ympäröivän ilman kaasukoostumus ja joillekin lajeille myös valo. Rypsillä optimaalinen kylvöaika, kylvösyvyys, lämpötila, kylvömäärä ja ravinteet sekä riittävä kosteus ovat tärkeitä tekijöitä nopeassa ja täydellisessä itämisessä ja kasvuun lähdössä. Kun rypsikasvusto on taimettunut, tuholaiset ja joinakin vuosina myös hallat voivat harventaa tai jopa tuhota rypsikasvuston.

Tässä esityksessä käsitellään kylvöajan, kylvömäärän, kylvösyvyyden ja itämislämpötilan vaikutuksia rypsin itämiseen ja alkukehitykseen. Kasvun stimulointi ravinteita sisältävillä pinnoitteilla on antanut lupaavia tuloksia viljoilla, joten niiden vaikutusta myös rypsin taimettumiseen ja jälkikehitykseen selvitettiin. Lisäksi käsitellään riskejä, joita rypsi kohtaa taimettumisen jälkeen. Mukana on tuloksia juuri päättyneestä "Rypsin viljelyvarmuuden parantaminen" -projektista sekä myös aikaisemmista tutkimuksista.

Rypsin taimettumisaika oli 17 vrk $5{ }^{\circ} \mathrm{C}$ lämpötilassa, 10 vrk $15{ }^{\circ} \mathrm{C}$ :ssa. Aikainen kylvö heti maan tultua kylvökuntoon vähensi kasvuston tiheyttä ja korkeutta verrattuna noin kaksi viikkoa myöhempään kylvöön. Karaistunut rypsikasvusto kesti sirkkalehtiasteella hyvin $-3{ }^{\circ} \mathrm{C}$ hallaa, mutta -5 ${ }^{\circ} \mathrm{C}$ :ssa menetettiin puolet taimista. Pinnoituspolymeerien käyttö rypsin kylvöä ajoitettaessa ei ollut kovin lupaavaa. Rypsi taimettui parhaiten $0-2,5 \mathrm{~cm}$ :n syvyydestä, jos maassa oli riittävästi kosteutta. Osa siemenistä säilyi hengissä $20 \mathrm{~cm}$ syvyydessä. Kylvämällä 250 itävää siementä/ $\mathrm{m}^{2}$ saatiin aikaan optimikylvöolosuhteissa kasvusto, jonka yksilömäärä oli $180 \mathrm{kpl}$ neliömetrillä, tiheys, jonka jälkeen ei saavutettu enää sadonlisäystä. Siemenriviin annettu typpilannoitus $(10 \mathrm{~kg} / \mathrm{ha})$ hidasti taimettumista kasvihuonekokeessa. Fosforin käytöllä siemenen kuorruttamisessa saatiin vaihtelevia tuloksia, joihin vaikutti vuosi, lajike ja kasvupaikka.

Asiasanat: rypsi, siemen, itäminen, kylvöaika, kylvösyvyys, kylvömäärä, ravinteet 


\section{Johdanto}

Suomi on rypsinviljelyn pohjoisimpia alueita. Kasvukauden lyhyys on määräävä tekijä rypsin viljelyssä ja jalostuksessa. Rypsi kylvetään pääviljelyalueella yleensä toukokuun kahden ensimmäisen viikon aikana. Tärkeimpiä tekijöitä rypsin viljelyn onnistumisessa on tasainen ja nopea taimettuminen, jolloin myös edellytykset kasvuston hyvälle jatkokehitykselle ovat olemassa. Riittävän nopea taimettuminen heikentää rikkakasvien kilpailua ravinteista ja lyhentää tuholaisille altista taimivaihetta.

Rypsin itämiseen ja kasvun alkuun tarvitsemat eväät ovat hyvin energiapitoisessa, mutta pienessä siemenessä, jonka koko on vain kymmenesosa viljan jyvästä. Tämän vuoksi oikea kylvömäärä, kylvösyvyys ja kylvöaika sekä riittävä veden saatavuus ovat tärkeitä tekijöitä nopeassa ja täydellisessä itämisessä ja kasvuun lähdössä. Riittävä kosteus ja oikea lämpötila määrittävät optimikylvöajan. Kasvun stimulointi ravinteita sisältävillä pinnoitteilla on antanut lupaavia tuloksia viljoilla, joten niiden vaikutusta myös rypsin taimettumiseen ja jälkikehitykseen selvitettiin.

Tässä esityksessä käsitellään kylvöajan, kylvömäärän, kylvösyvyyden, itämislämpötilan, typpiyhdisteiden ja starttifosforinpinnoituksen vaikutuksia rypsin itämiseen ja alkukehitykseen. Lisäksi käsitellään riskejä, joita rypsi kohtaa taimettumisen jälkeen. Mukana on tuloksia juuri päättyneestä "Rypsin viljelyvarmuuden parantaminen" -projektista sekä myös aikaisemmista tutkimuksista.

\section{Rypsin siemenen rakenne ja itäminen}

Elinkykyisten siementen tuottaminen ja mahdollisimman pitkälle myös niiden jatkokehityksen turvaaminen on kasvin elämänkierron tärkein tehtävä. Siemenissä on alkio ja siemenvalkuainen eli endospermi, joita ympäröi siemenkuori. Ristikukkaisilla kasveilla siemenvalkuainen on surkastunut, ja itämiseen tarvittava vararavinto (öljy, hiilihydraatit, valkuaisaineet) on pääasiassa lähes koko siemenen täyttävässä alkiossa, tarkemmin sen sirkkalehtien soluissa. Siemenen itämisen edellytyksenä on riittävä kosteus, sopiva lämpötila ja ympäröivän ilman oikea kaasukoostumus. Joillekin lajeille myös valo on tärkeä itämisen edellytys.

Itämisen ensimmäisessä vaiheessa alkaa veden nopea imeytyminen siemeneen. Rypsin siemenen pinnassa uloimpana on selluloosasta ja pektiinistä koostuva kerros, joka kostuessaan muodostaa siemenen pinnalle hyytelömäisen kalvon (Pyykkö 1980). Seuraavassa vaiheessa vedenotto hidastuu tai jopa lakkaa vähäksi aikaa, entsymaattinen aktiivisuus ja meristeemiset muutokset alkavat. Itämiskykyisillä siemenillä vedenotto nopeutuu uudelleen, siemenkuori rikkoutuu, ja sirkkajuuri työntyy esiin. Vesi imeytyy siemeneen siihen asti, kun yksikin osa siemenkuoresta on yhteydessä veteen. Itäessä sirkkalehdet nousevat sirkkavarren kannattamina maanpinnalle nostaen siemenkuoren jäännökset mukanaan (epigeeinen itäminen) (Mayer \& Poljakoff-Mayber 1982).

\section{Kasvuun lähtöä varmentava tekijät}

\section{Kylvöaika}

Oikea kylvöaika vaikuttaa rypsin taimettumistiheyteen. Vuonna 2003 kylvettiin rypsiä kolmena eri ajankohtana. Aikaisin kylvö tehtiin heti, kun se oli teknisesti mahdollista 29.4., keskimmäinen "normaaliin aikaan" 20.5. ja myöhäisin toukokuun viimeisenä päivänä. Tarkoituksena oli hakea erilaisia kosteusoloja rypsin itämiselle ja taimettumiselle. Saatu taimettumistulos vastasi melko hyvin aikaisempia tutkimustuloksia, joissa aikaisin kylvö antoi neljänneksen ja myöhäisin noin 10 prosenttia pienemmän taimimäärän kuin optimiaikaan tehty kylvö (Köylijärvi 1989). Aikaisen kylvön riskinä ovat epätasainen ja hidas itäminen maan alhaisen lämpötilan vuoksi, mikä kuluttaa siemenen vararavintoja. Tuholaiset ovat kerkeästi liikkeellä taimelle ehtineissä kasvustoissa päivän lämpiminä hetkinä. Myös pakkasvaurioita voi esiintyä hyvin aikaisin kylvetyissä kasvustoissa. Aikaisin kylvettäessä saattaa suurempi siemenmäärä olla avuksi tiheän kasvuston aikaansaamisessa.

Koska optimiolosuhteita rypsin kylvöön on harvoin tarjolla, "Rypsin viljelyvarmuuden parantaminen" -projektissa etsittiin myös mahdollisuuksia edistää rypsin kasvuun lähtöä kehittämällä siemenen päällystysteknologiaa hyödyntäviä menetelmiä siten, että rypsin kylvön ajoitusta voitaisiin 


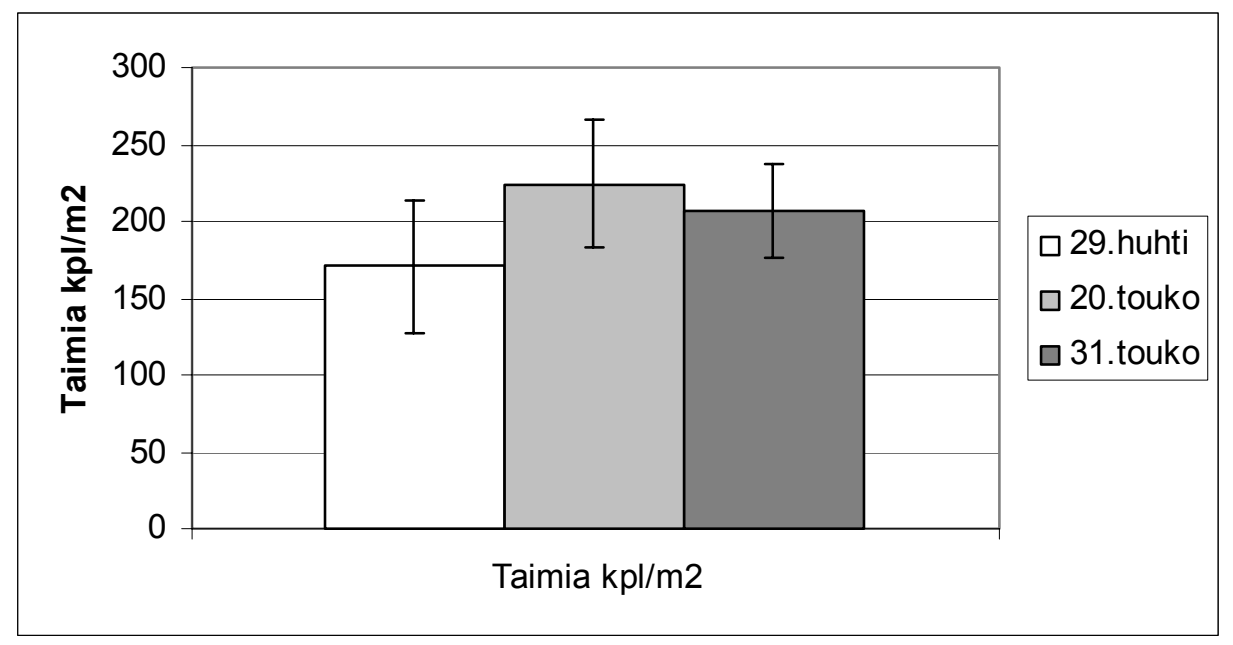

Kuva 1. Rypsikasvuston taimimäärä neliömetrillä rypsin 2-lehtiasteella. Rypsi kylvetty 29.4., 20.5. ja 31.5. 2002. Jokioinen. Kylvömäärä $300 \mathrm{kpl}$ itäviä siemeniä/m².

joustavammin vaihdella Suomen kasvuoloissa. Kanadassa kehitetyssä menetelmässä erilaisilla polymeereillä pinnoittamalla voidaan viivyttää tai estää siemenen itämistä epäedullisissa oloissa, jolloin siemenen kylvöaika voi olla esim. myöhään syksyllä. Näin voitaisiin välttää kevätmuokkauksen tuoma työmäärä ja mahdollisesti nopeuttaa kasvuun lähtöä. Menetelmää kokeiltiin projektissamme kylvämällä pinnoitettuja (GrowTec Extender ${ }^{\circledR}$, Poligen-polymeeri) rypsin ja rapsin siemeniä syksyllä juuri ennen talventuloa ja hyvin aikaisin keväällä maan ollessa vielä jäässä. Ensimmäisenä vuonna saatiin aikaan kohtuullinen kasvusto, mutta sato oli huomattavasti heikompi kuin perinteisellä kylvötavalla aikaansaatu kasvusto. Aikaisin taimettuneet öljykasvit houkuttelivat tuholaisia, ja torjuntatoimista huolimatta kasvustot tuhoutuivat muina koevuosina. Menetelmä kaipaa vielä melkoista kehittämistä, jos sitä aiotaan jatkossa käyttää Suomen oloissa (Peltonen-Sainio ym. 2005).

\section{Kylvösyvyys}

Kylvösyvyyden vaikutus rypsin siementen kasvuun lähtöön on huomattava. Rypsi taimettuu nopeimmin matalaan tai jopa aivan maanpintaan kylvettynä edellyttäen kuitenkin, että siemen ei pääse kuivumaan missään vaiheessa (Taulukko 1). Kylvettäessä liian syvään valon puute voi aiheuttaa lepotilan (Woolley \& Stoller, 1978), joka laukeaa vasta siemenen joutuessa uudelleen lähelle maanpintaa, jos muut olosuhteet itämiselle ovat suotuisat.

Taulukko 1. Rypsin taimettuminen eri syvyyksistä keväällä ja syksyllä (Pahkala 2003).

\begin{tabular}{ccc}
\hline \multirow{2}{*}{ kylvösyvyys } & \multicolumn{2}{c}{ Kylvöpäivä } \\
\cline { 2 - 3 } & 27.5. & 23.9. \\
\hline $0,0 \mathrm{~cm}$ & $40 \mathrm{a}^{1}$ & $81 \mathrm{a}^{1}$ \\
$2,5 \mathrm{~cm}$ & $89 \mathrm{~b}$ & $60 \mathrm{~b}$ \\
$5,0 \mathrm{~cm}$ & $51 \mathrm{a}$ & $43 \mathrm{c}$ \\
$7,5 \mathrm{~cm}$ & $11 \mathrm{c}$ & $4 \mathrm{~d}$ \\
$10,0 \mathrm{~cm}$ & $1 \mathrm{~d}$ & $0 \mathrm{e}$ \\
$15,0 \mathrm{~cm}$ & $0 \mathrm{e}$ & $0 \mathrm{e}$ \\
$20,0 \mathrm{~cm}$ & $0 \mathrm{e}$ & $0 \mathrm{e}$ \\
\hline
\end{tabular}

${ }^{1)}$ Eri kirjaimella merkityt sarakkeen luvut eroavat toisistaan merkitsevästi $(\mathrm{P}<0,05)$. 


\section{Lämpötila}

Rypsin itäminen hidastuu tai estyy alhaisessa lämpötilassa. Kun rypsiä idätettiin 5, 10, 15 ja 20 asteen lämpötiloissa, saavutettiin yhtä suuri itävyys kaikissa lämpötiloissa. Itäminen oli kuitenkin selvästi hitaampaa alemmissa lämpötiloissa (Kuva 2) (Pahkala 2003). Kun taimissa oli 2-3 kasvulehteä, viileässä kasvaneet taimet olivat tummemman vihreitä ja selvästi painavampia kuin lämpimämmässä kasvaneet taimet.

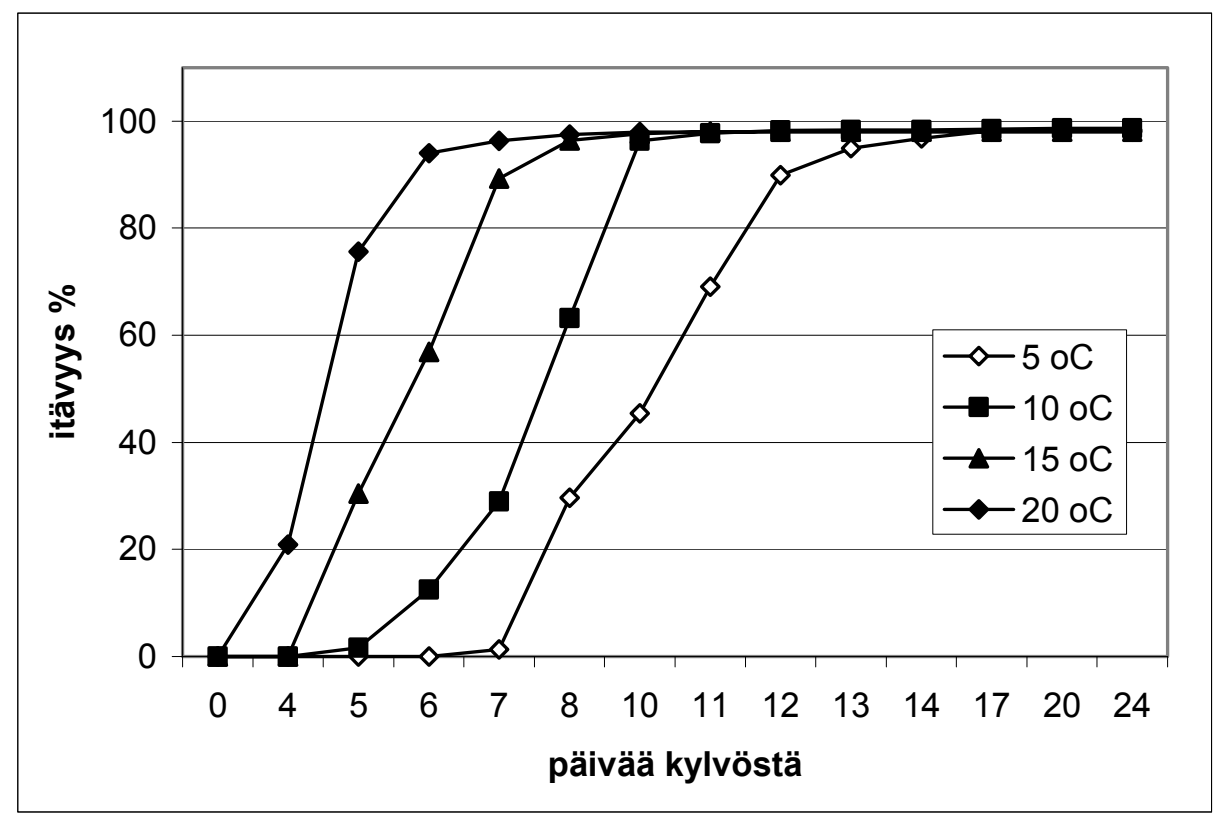

Kuva 2. Lämpötilan vaikutus rypsin itämiseen (Pahkala 2003).

\section{Kylvömä̈̈rä}

Kylvömäärä laskettuna itävinä siemeninä/ $\mathrm{m}^{2}$ on hyvin tehokas keino vaikuttaa taimitiheyteen. Maksimisadon tuottava kasvitiheys vaihtelee vuosittain. Jos kasvustot ovat ylitiheitä, litujen tuotanto tapahtuu vain päävarressa. Haarattomat kasvit tuottavat vähemmän lituja ja satoa pinta-alayksikköä kohden kuin harvempi kasvusto, jossa kasveilla on tilaa tuottaa myös sivuhaaralituja. Näin ylimääräisten kilojen kylväminen lisää vain kustannuksia. Tutkimuksissa ei saavutettu enää merkittävää sadon lisäystä, kun rypsiyksilöiden määrä neliömetrillä ylitti $180 \mathrm{kpl}$. Tähän tiheyteen päästiin optimioloissa kylvämällä 250 itävää siementä/m² (Sankari \& Pahkala 1994). Aikaisessa kylvössä tätä suuremmat siemenmäärät varmistavat kuitenkin tasaisen kasvuston syntymisen.

\section{Ravinteet}

Typpi

Ristikukkaisten öljykasvien siementen idätyksessä käytetään kaliumnitraattia itämisen stimuloinnissa (International rules for seed testing 2005). Astiakokeissa kylvöriveihin annettu typpilisäys (nitraatti-, ammonium-, ureatyppi), joka vastasi $10 \mathrm{~kg} / \mathrm{ha}$, hidasti taimettumista, mutta viikon kuluttua kylvöstä ei eroja enää ollut havaittavissa. Typpilisäyksen saaneissa taimiriveissä oli myös enemmän epänormaaleja taimia (Pahkala 2003). Rypsin itämisvaihe on erittäin arka ulkoisille olosuhteille, mihin voidaan lukea myös vaihtelut ravinteiden määrissä aivan siemenen välittömässä läheisyydessä.

\section{Fosfori}

Fosforilla on merkittävä osa kasvin energia-aineenvaihdunnassa, hengityksessä ja yhteyttämisessä. Myös siementaimen kehittymiseen fosforin saatavuudella on tärkeä merkitys. Fosfori on siemenessä fytiinihappona, joka pienen rypsin siemenen itäessä kuluu nopeasti loppuun. Sen jälkeen itävä rypsin siemen on riippuvainen fosforin ulkoisesta saannista. Maaperässä oleva fosfori on vaikeasti kasvin 
saatavilla (Saarela et al. 2002) ja lannoiterakeissa annettu fosfori siemenestä noin $7 \mathrm{~cm}: n$ päässä, mistä se ei hevillä liiku sivulle päin varsinkaan maan ollessa kylmää.

Kemira GrowHow Oyj on kehittänyt menetelmän kylvösiemenen pinnoittamiseksi starttifosforilla. Tämä iSeed-menetelmä on osoittautunut toimivaksi esimerkiksi kauralla, jonka jyvään fytiinihappona varastoidusta fosforista vain osa hajoaa itämisen yhteydessä sirkkataimen kasvun tarpeisiin. Myös öljykasveilla vuosina 2002 ja 2003 Latviassa, Liettuassa, Virossa ja Ruotsissa saatiin muutamissa kokeissa selviä sadonlisäyksiä (Peltonen 2003). "Rypsin viljelyvarmuuden parantaminen" projektissa tutkittiin kolmena vuonna iSeed-menetelmän soveltuvuutta rypsin taimettumisen edistämiseen neljällä koepaikalla. Menetelmän vaikutukset olivat joko negatiivisia, vaihtelevia tai lievästi positiivisia. Lajikkeet (Valo ja Kulta) reagoivat vuodesta ja koepaikasta riippuen hiukan eritavalla iSeedkäsittelyihin. Kuivissa oloissa vuonna 2002 käsittely haittasi taimettumista. Vuonna 2003 vaikutukset vaihtelivat koepaikkakohtaisesti siten, että vaikutukset Valoon olivat Jokioisissa lievästi negatiivisia, mutta Hahkialassa molempien lajikkeiden sato parani iSeed-käsittelyjen tuloksena. Muilla koepaikoilla lajikkeiden vaikutus oli suurempi kuin käsittelyjen vaikutus. Vuonna 2004 Valon satovaste oli käsitellyissä koejäsenissä positiivinen kaikilla neljällä koepaikalla ja Kullan yhdellä koepaikalla. Havaintojemme mukaan iSeed-pinnoitettu rypsi iti toisinaan kontrollia hitaammin. Veden imeytymisnopeudella saattoi olla vaikutuksia erityisesti kuivina vuosina. Tutkimusvuosina iSeed -kokeissa oli runsaasti kirppoja, mutta eri käsittelyiden ja lajikkeiden välillä ei kuitenkaan havaittu eroa vioitusmäärissä.

\section{Rypsikasvuston riskit taimettumisen jälkeen}

\section{Tuholaisten esiintyminen ja torjunta}

Kirpat ovat rypsin taimivaiheen pahimpia tuholaisia. Ne syövät rypsin taimiin koloja ja reikiä, jolloin haihdunta lisääntyy ja yhteyttävä lehtiala pienenee. Kirpat vioittavat etenkin aikaisin kylvettyjä sekä kuivissa oloissa hitaasti ja epätasaisesti taimettuvia kasvustoja.

Kirppoja torjutaan kemiallisesti peittaamalla kylvösiemen hyönteistorjunta-aineella. Siementen peittaus tehdään keskitetysti, ja sertifioitu siemen on yleensä peitattua. Peittaukseen käytetään tavallisimmin Cruiser OSR -valmistetta, jonka tehoaineena ovat tiametoksaami, metalaksyyli-M ja fludioksiniili. Myös imidaklopridi- ja beta-syflutriini -tehoaineita sisältävän Chinook FS 200 -valmisteen käyttö on sallittua, mutta vähäistä. Vaikka taimista löytyy joitain syöntijälkiä, se ei välttämättä merkitse, että peittausaine ei tehoa. Peittausaineen teho kuitenkin heikkenee, jos kasvuston taimettuminen viivästyy ja kylvöstä kuluu riittävän kauan. Jos kirppoja esiintyy runsaasti kasvien sirkkalehtivaiheessa, voidaan peittauksesta huolimatta joutua ruiskuttamaan taimet vielä pyretroidi-valmisteilla. Jos kasvuston taimettuminen on hidasta ja epätasaista, voidaan torjuntaruiskutus joutua uusimaan tai pahimmassa tapauksessa tekemään uusintakylvö. Sirkkalehtivaiheen jälkeen rypsi kehittyy yleensä nopeasti eikä kirpoista enää ole pahemmin haittaa.

\section{Pakkasvauriot}

Rypsikasvusto voi harventua myös hallojen seurauksena. Vuonna 2004 rypsi kärsi paikoitellen pahoja hallavaurioita 14.5. ollessaan sirkkalehtiasteella. Alimmat lämpötilat $2 \mathrm{~m}$ korkeudessa Jokioisissa olivat $-4{ }^{\circ} \mathrm{C}$ ja maanpinnassa $-8{ }^{\circ} \mathrm{C}$. Rypsin vaurioitumiselle on tyypillistä, että taimien paleltumista ei välttämättä heti havaita. Vaurio pahenee noin viikon ajan.

Kasvatuskaapissa järjestettiin koe, jossa yölämpötila oli $5{ }^{\circ} \mathrm{C}$ ja päivälämpötila $16{ }^{\circ} \mathrm{C}$, mikä vastasi melko tavallisia kevätolosuhteita. Sirkkataimet altistettiin muutaman tunnin yöpakkaselle $\left(-3{ }^{\circ} \mathrm{C}\right.$ ja $-5{ }^{\circ} \mathrm{C}$ ). Taimissa $-3{ }^{\circ} \mathrm{C}$ halla ei aiheuttanut näkyviä vaurioita, mutta $-5{ }^{\circ} \mathrm{C}$ :een aiheuttamat vauriot näkyivät jo kahden tunnin päästä, ja ne pahenivat 26 tunnin kuluessa. Kuuden päivän päästä yli puolet vahingoittuneista taimista oli kuollut. Myös lajikkeiden hallankestävyydessä havaittiin eroja. Aikaisemmin viljelyssä olleen Emman (0-lajike) kestävyys oli parempi kuin kokeessa olleiden uudempien 00-lajikkeiden (Pahkala ym. 1992). Pelto-olosuhteissa taimet saattavat kestää ankarampaa hallaa kuin kasvatuskaapissa. 


\section{Kirjallisuus}

Goudey, J.S., Saini, H.S. \& Spencer, M.S. 1988: Role of nitrate in regulating germination of Sinapis arvensis L. (wild mustard). Plant, Cell and Environment 11, 9-12.

International rules for seed testing. 2005. Germination. International Seed Testing Association, Zürich.

Känkänen, H., Pahkala, K., Antinluoma, E. \& Peltonen-Sainio, P. 2003. Improving establishment and early growth of spring turnip rape. In: Proceedings of the $11^{\text {th }}$ International Rapeseed Congress, July 6-10 2003, Copenhagen, Danmark. p. 797-799.

Köylijärvi, J. 1989. Kevätöljykasvien kylvömuokkaus ja kylvö. Maatalouden tutkimuskeskus. Tiedote 11/89: 11-37.

Mayer, A.M. \& Poljakoff-Mayber, A. 1982. The germination of seeds. Oxford. Pergamon Press. 211 p.

Pahkala, K. 1987. Lämpötilan vaikutus rypsin itämiseen. Koetoiminta ja Käytäntö 27.1.1987.

Pahkala, K. 2003. Germination and establishment of spring sown oilseed crops. Proceedings of the $11^{\text {th }}$ International Rapeseed Congress, July 6-10 2003, Copenhagen, Danmark. p.

Pahkala, K., Laakso, I. \& Hovinen, S. 1992: The effect of frost treatment on turnip rape seedlings, ripening seeds and their fatty acid composition. In: Proceedings of the $8^{\text {th }}$ International Rapeseed Congress, July 9-11 1991, Saskatoon, Canada. p. 1749-1753.

Peltonen, J. 2003. Projektin sisäinen tiedonanto.

Peltonen-Sainio, P., Känkänen, H., Pahkala, K., Salo, Y., Huusela-Veistola, E. \& Peltonen, J. 2005. Polymer coated turnip rape seed did not facilitate earlier sowing under Finnish growing conditions. (käsikirjoitus)

Pyykkö, M. 1980. Kasvianatomia. Hämeenlinna, Gaudeamus. 292 p.

Saarela, I., Järvi, A., Hakkola, H. \& Rinne, K. 2003. Phosphorus status of diverse soils in Finland as influenced by long-term P fertilization. I Native and previously applied P at 24 experimental sites. Agric. Food Sci. Finland 12: 117-132.

Woolley, J.T. \& Stoller, E.W. 1978: Light penetration and light-induced seed germination in soil. Plant Physiology 61: 597-600. 